\title{
Duterte's Polemic Against the Catholic Church as Hate Speech
}

\author{
Yvonne T. Chua and Ma. Diosa Labiste
}

This study examines thirteen speeches of President Rodrigo Duterte that contain lines, paragraphs, and expletives directed against the Roman Catholic Church, to determine if they are forms of hate speech. These speeches were delivered from August 2016, two months after he assumed office, up to May 2017. These rhetorical resources were directed toward the Church and its clergy, which criticized Duterte's war on drugs, and they have been analyzed using a modified version of the dangerous speech framework of the U.S.-based Dangerous Speech Project (Benesch, 2013), which has five rhetorical elements: speaker, content and its context, audience, medium, and response. This study defines hate speech as a speech that attacks personal dignity, dehumanizes groups, incites discrimination, advocates hostility, creates a social wedge, and imputes a crime.

Keywords: hate speech, speech acts, counterspeech

\section{Duterte's Polemic Against the Catholic Church as Hate Speech}

In his first year in office, President Rodrigo Duterte sealed his reputation as a disagreeable public speaker, one that curses and badmouths his critics. A number of his profanity-laden speeches targeted the Roman Catholic Church. His polemic against the Church often happened when it was least expected, on occasions such as a road inauguration, a meeting with migrant workers, or a visit to a military camp. And thanks to the state-owned media and the presidential office, which provide transcripts and videos of the speeches, Duterte's anti-Church statements were easily amplified in private media and partisan social media sites.

In terms of style, Duterte's speeches are unconventional. They are characterized as folksy and are delivered extemporaneously. They are also termed "very raw" or "direct, unedited and no pretensions" (Cunanan, as cited in Maslog, 2017, p. 9). In his public appearances, Duterte often rambles, ignores the written scripts, and then trails off mid-sentence. However, this study argues that the occurrences of anti-Church sentiments in Duterte's 
speeches are far from random. In fact, there appears to be a template or script for these diatribes. For example, in some of the speeches examined in this study, Duterte claimed that the priests and bishops are sex offenders and that they are corrupt, getting rich at the expense of the faithful (Presidential Communications Operations Office, 2016a). He even said, "Patya (ka)nang pari [Kill the priest]" (Presidential Communications Operations Office, 2017e, para. 137). On some occasions, he suggested that the priests were inviting harm unto themselves (Presidential Communications Operations Office, 2016a). Then, at the close of the five-to-fifteen-minute harangue, Duterte would give away a copy of Altar of Secrets, the late journalist Aries Rufo's book about corruption and sexual indiscretions of some bishops, to the audience (Presidential Communications Operations Office, 2017g).

This study asks: Does Duterte's polemic against the Catholic Church constitute a form of hate speech? The Philippines has no legislation on hate speech although it has libel and defamation laws (Fact-Checkers Legal Support Initiative, 2019). In this study, we argue that hate speech is not only used to ruin the reputation of groups, individuals, or communities but also to instill fear, sow discrimination, and create a social wedge. Without a legal basis, hate speech may be difficult to conceptualize in the context of the Philippines that values free expression that has been enshrined in its Constitution. However, we believe that by examining hate speech, this study will contribute to identifying the phenomenon, as represented by Duterte's hateful words, that has denigrated and vilified the Church. This study asks: Does Duterte's polemic against the Catholic Church constitute a form of hate speech?

\section{Presidential Speeches as Public Acts}

Presidential speeches are public acts that allow the president to directly talk to an audience without the mediation of media. There is a privileged proximity between the president and the audience that listens to the speech. However, the occasion remains public in the sense that the president, as speaker, commits himself to a linguistic performance expected of a public official. Such performance would consider, if not presuppose, deferential interaction with the listeners.

The sense of "publicness" in public speaking is not dependent upon the occasion or the location but on the telos of public speaking. As Jurgen Habermas (1989) put it, the speech act, which includes its purpose and its effects, allows for the "public use of reason" (p. 27). The use of reason refers less to the manner of dealing with vexed confrontation but more to creating utterances that inform citizens about issues that matter to them. The information sharing is important before the public can decide and act accordingly. For Habermas, being in the public realm, speech acts 
promote mutual understanding and common welfare. In other words, the use of reason in a speech act intends to create consensus. Thus, following Habermas, one can say a speaker is obliged to communicate his or her wellintentioned thoughts because listeners will consider them to form public opinion.

Speech acts are public acts in which respect is anticipated. Both Axel Honneth (2008) and Jeremy Waldron (2012) conveyed the notion of reciprocal respect. Honneth (2008) defined recognition as having an "existential sympathy for the other" and expressing some "forms of concern or benevolence" (p. 152). Honneth favored recognition over consensus because respect should remain, no matter the differences between communicating individuals and among publics. Respect, in Honneth's term, is "antecedent recognition" (p. 63) toward people and their sentiments.

Corollary to this view is Waldron's (2012) idea of anticipated respect, which argues that a person deserves to be treated as "an equal of everyone" (p. 5). Dignity, he said, is denied if the speech act or the speech itself is deliberately "abusive, insulting, threatening or demeaning" and "stirs up hatred" (p. 8) against an individual or a group. Not only does this kind of speech impede understanding but it also "pollutes the social environment of a community and makes life much more difficult for many of those who live in it" (p. 16). Moreover, Waldron said that effects of hateful speech work two ways. First, it targets a group with the intent to dehumanize and diminish its members. Second, it conveys to others, who share similar views with that of a vilified group, that they are also under threat.

\section{Hate Speech}

International human rights frameworks that guarantee free expression disapprove of hate speech. The 1948 Universal Declaration of Human Rights (UDHR) raises implicit concern on hate speech in Article 7, which provides for "equal protection against any discrimination" and "against incitement to such discrimination" ("Universal Declaration of Human Rights," n.d.). On the other hand, the International Covenant on Civil and Political Rights (ICCPR) contains Articles 19 and 20 that, taken together, address hate speech without using the term ("International Covenant on Civil and Political Rights," n.d.). Article 19 provides for the right to free expression that includes the freedom to seek, receive and impart information of all kinds" and "for respect of the rights and reputation of other" (Section 3a), while Article 20 states that any advocacy of "hatred that constitutes incitement to discrimination, hostility or violence shall be mostprohibited by law" (Section 2)

A UNESCO study notes that the simultaneous interpretation of Articles 19 and 20 should not weaken each provision's guarantees and limitations 
(Gagliardone, Gal, Alves \& Martinez, 2015). The issue here is the possibility that the elements in Article 20 may suppress what are allowed in Article 19, such as criticism and debate on ideas, beliefs, ideologies, religion, or religious institutions. In short, freedom of expression and freedom from discrimination are not incompatible principles of law. In juxtaposing the two ICCPR articles, the study highlights the need to balance the guarantees of free expression in relation to what is construed as hate speech because debates on their relationship could be complicated in some national or cultural contexts.

Garliardone et al. (2015), however, recognized the differing interpretations of the term hate speech. Even in countries that have laws on hate speech, and also in the growing global scholarship, the term remains contested. Hate speech is no longer strictly defined as a speech that incites harm as definitions have converged around the idea that it is speech that creates a social wedge. Hatred could arise out of antagonisms involving race, nationality, ethnicity, class, religion, gender, and sexual orientation. Given the difficulty of defining hate speech, the UNESCO sees a chance to develop "shared local interpretations of the international standards" (p. 55). Such challenge is taken up in this study, which intends to form an understanding over what constitutes hate speech, as seen through Duterte's speeches.

This study presupposes that the performative aspect of the speech is inextricable from the speech itself. Judith Butler (1997) posited that in hate speech as a speech act, the way of saying and doing is as important as the language used (p. 96). By calling attention to the performative element of the speech, particularly the use of some rhetorical effects, this study will highlight two things: first, the semiotic power of words, and second, their use in hate speech.

\section{Rhetoric and Politics}

Duterte's populist politics provides context for his loquacity. Duterte, the 16th president of the Philippines, came to power via a mandate from 16 million voters, beating his rivals who were ahead of him in terms of campaign machinery and media mileage ("Philippine Congress Confirms Duterte Won Presidential Eelection," 2016). His campaign promise was simply to crack down on criminality and drug use by any means necessary (Jiao, 2017).

It wasn't that Duterte was a dark horse in politics. For 22 years, he was the mayor of Davao City where he earned notoriety for his massive and deadly crackdown of alleged criminals and drug users and sellers ("Philippines' 'War on drugs", 2017). Behind the killings of petty thieves and drug suspects was the Davao Death Squads, the dreaded vigilante group that reportedly took orders from Duterte, although this was never proven in court even 
after calls by the Commission on Human Rights to investigate him for administrative and criminal responsibility (Amnesty International, 2017). Duterte capitalized on this reputation during his successful presidential bid, in which his campaign statements foreshadowed his rule that is now noted for pervasive extrajudicial killings, warrantless arrests, and vilification of his critics, among them the Roman Catholic Church.

When he became president, Duterte's anticrime stance was well received by the elite, middle class families, and migrant workers. What Duterte succeeded in doing was to put in place an immobilizing fear of drugs and criminality. However, this fear was without empirical proof to warrant a drastic solution like killing suspected users of crystal meth, locally termed "shabu." Duterte's approach toward criminality evokes Stanley Cohen's (1972) concept of "moral panics," where a "condition, episode, person or group of persons emerges to be defined as a threat to societal values and interests" (p. 1). While moral panics were initially bound up with the British working class' subcultures and deviancy, Cohen expanded its scope in 2002 to account for public anxieties on refugees, single mothers, drug use, child abuse, and pedophilia. He said these issues could easily generate moral revulsions that deviants such as drug users have to be shamed, controlled, or eliminated.

Duterte's punitive acts are accompanied by virulent language that he uses to denigrate drug suspects and critics of his drug policy ("Philippines: Duterte's First Year a Human Rights Calamity," 2017). Broadcasted through state and private media, Duterte's statements paint a society where law and order are at their breaking point. Cohen (2002) designates a similar process he calls "inventory," which is resorted to by news media. Inventory works through the tropes of exaggeration, distortion, and stereotyping directed at "Mod and Rockers" that represent an abuse of language. In all tropes, moral panics create an atmosphere of hatred and fear while the repulsion of the Other generates a highly charged and morally constructed language. Arguably moral panics are generative of hate speech.

Presidential speeches are political acts in which a president connects to the public through rhetorical means. However, according to David Michael Ryfe's (2005) idea of "rhetorical presidency," (p.8) the larger purpose of the presidential rhetoric is setting the terms of political discourse and framing the issues to be discussed. Ryfe argued that presidential rhetoric "defines politics reality" (p. 9). His arguments are reminiscent of the agenda-setting function of the news media, which identifies the key issues of the day and their ability to influence the salience of these issues (McComb, Shaw, and Weaver, 2014, p. 1). Subsequently, from both McCombs et al. and Ryfe's perspectives, the public can form their own agenda and decide which issues are important. 
Presidential speeches, as a form of political discourse, are worked through argumentation or the application of reason in order that the speaker's rights, commitments, and moral values are worthy of being recognized. However, not all argumentation is reasonable; sometimes its purpose is to constrain, coerce, or vilify people instead of foster mutual understanding (Fairclough \& Fairclough, 2012). Given that presidential speeches presuppose their acceptance due to their status function, listeners might be induced to believe that even their unreasonable arguments are legitimate and justified.

\section{Methodology}

This study examines the anti-Church language in the speeches of Duterte to determine if it is a form of hate speech. It offers a way of analyzing the speeches through content-related analysis of claims. Content-related analysis is not a full-blown content analysis of all the speeches but a limited one, targeting only the claims or statements of Duterte that are against the Church. This study shows how the context of Duterte's presidential speeches and the values and goals represented in the premises of their arguments could constitute hate speech. It demonstrates a way of critiquing controversial and exclusionary claims of speech act, in which the analysis will be worked out on the basis of empirical data, using an existing catalogue of analyzing dangerous speech.

The combination of content-related analysis and rhetorical analysis will look at the language and the performative aspect of Duterte's speeches. The first analysis will investigate the specific content that attacks personal dignity, dehumanizes groups, incites discrimination, advocates hostility, creates social wedge, and imputes a crime. These semiotic strategies suggest an exclusionary agenda because it criticizes a person or a group in a way that is degrading.

Aside from content, it can be argued that hate speech presents a distinct form of rhetoric that instrumentalizes language in order to produce fear out of prevailing dissatisfaction, pessimism, and inequality. In his famous treatise The Rhetoric, Aristotle defined rhetoric as the "power of discovering the means of persuasion in any given situation" (as cited in Kuypers \& King, 2009, p. 2). Jim Kuypers and Andrew King defined rhetoric as an instrumental way of using language, that is, "the strategic use of communication, oral or written, to achieve specific goals" (p. 4). The term "strategic" relates to the intention of the communicator that has to be inferred by the audience (p. 6). The purposive aspect of rhetoric suggests that a speech act is never random and stray-the language and the way of saying are intentional. But persuasion requires the negotiation of meaning between the speaker and 
the audience; it is a process that counts on context and discourse ethics (Kuypers and King, 2009).

Since rhetoric is mindful of the capacity of the audience to make sense of the communicative process, Kuypers and King argued (2009) that such act is ethical and for which the rhetor or speaker is held accountable (p. 8). This ethical responsibility is anchored on democracy, specifically deliberative democracy, that is evident in the works of Honneth, Waldron, and even the authors of the UNESCO study.

Rhetoric has a deliberative import, and it is underpinned by the premise of reciprocal respect that should rise above "unbridgeable controversies and sedimented suspicion" (Kuypers \& King, 2009, p. 10). If the rhetor does not honor ethical responsibility and mutual respect, which occurs, for example, when one maligns the Church, then deliberative democracy or free discussions among citizens cannot apply. The use of rhetorical criticism techniques intends to tease out the presence of normative reciprocal respect, which is either noticeable or missing in Duterte's.

Rhetorical critics study instances of rhetoric, also called "rhetorical artifacts," to appreciate and understand how the rhetor seeks to influence audience behavior by having it "voluntarily agreeing with the speaker that a certain action or policy is better than another action or policy" (Kuypers \& King, 2009, p.10 ). This study specifically resorts to content-related analysis to describe and interpret presidential rhetoric. It adopts the broad definition of hate speech in Article 20 of the ICCPR - that "any advocacy of national, racial or religious hatred that constitutes incitement to discrimination, hostility or violence shall be prohibited by law" (United Nations Human Rights, n.d.) Purposive sampling is employed in selecting the rhetorical resources in the speeches of Duterte, the rhetor. All of them must have met one important criterion: They contain attacks on the Roman Catholic Church, including its officials, the clergy, and its beliefs and practices.

In all, this study purposively examines 13 speeches delivered between Aug. 31, 2016 and May 13, 2017. The speeches, all delivered in Duterte's first year in office, are significant: They presage what would be the president's continuing and escalating hostility toward the Roman Catholic Church. The study accessed verbatim recordings of Duterte's speeches in the form of video recordings and their corresponding transcripts made available by the Presidential Communications Operations Office (PCOO) through its website. The website provides a link to the videos, which are hosted on YouTube. 
Table 1. List of Duterte's Speeches Against the Roman Catholic Church

\begin{tabular}{|c|c|c|c|c|}
\hline Date & Occasion & Location & Text URL & Video URL \\
\hline $\begin{array}{l}\text { Aug. 31, } \\
2016\end{array}$ & $\begin{array}{l}\text { Message to } \\
\text { the Jesus } \\
\text { Anointed One } \\
\text { Church }\end{array}$ & $\begin{array}{l}\text { The Pinnacle } \\
\text { Hotel and } \\
\text { Suites, Davao } \\
\text { City }\end{array}$ & $\begin{array}{l}\text { http://pcoo.gov. } \\
\text { ph/aug-31-2016- } \\
\text { message-of- } \\
\text { president-rodrigo- } \\
\text { roa-duterte- } \\
\text { during-the-pastors- } \\
\text { enrichment- } \\
\text { program-pep- } \\
\text { 2016-for-their- } \\
\text { annual-religious- } \\
\text { convergence-of- } \\
\text { the-jesus-the- } \\
\text { anointed-one- } \\
\text { church-ja1/ }\end{array}$ & $\begin{array}{l}\text { https://www. } \\
\text { youtube.com/ } \\
\text { watch? v=D_- } \\
\text { QZUVrDT2A }\end{array}$ \\
\hline $\begin{array}{l}\text { Oct. 10, } \\
2016\end{array}$ & $\begin{array}{l}\text { Visit to Camp } \\
\text { Col. Romeo } \\
\text { Abendan - Po- } \\
\text { lice Regional } \\
\text { Office (PRO) } 9\end{array}$ & $\begin{array}{l}\text { Mercedes, } \\
\text { Zamboanga } \\
\text { City }\end{array}$ & & $\begin{array}{l}\text { https://www. } \\
\text { youtube. } \\
\text { com/ watch? } \\
\text { v=McTITO2wTQ4 }\end{array}$ \\
\hline $\begin{array}{l}\text { Dec. 27, } \\
2016\end{array}$ & $\begin{array}{l}\text { Christmas } \\
\text { gathering } \\
\text { with the } \\
\text { barangay of- } \\
\text { ficials }\end{array}$ & $\begin{array}{l}\text { Almendras } \\
\text { Gym, Davao } \\
\text { City }\end{array}$ & $\begin{array}{l}\text { http://pcoo. } \\
\text { gov.ph/dec-27- } \\
\text { 2016-speech-of- } \\
\text { president-rodrigo- } \\
\text { roa-duterte- } \\
\text { during-christmas- } \\
\text { gathering-with- } \\
\text { the-barangay- } \\
\text { officials/ }\end{array}$ & $\begin{array}{l}\text { https://www. } \\
\text { youtube. } \\
\text { com/watch? } \\
\text { v=RV49VOelkAA }\end{array}$ \\
\hline $\begin{array}{l}\text { Jan. 18, } \\
2017\end{array}$ & $\begin{array}{l}\text { 20th anniver- } \\
\text { sary of Pre- } \\
\text { miere Medical } \\
\text { Center }\end{array}$ & $\begin{array}{l}\text { Daan Sarile, } \\
\text { Cabanatuan } \\
\text { City, Nueva } \\
\text { Ecija }\end{array}$ & $\begin{array}{l}\text { http://pcoo. } \\
\text { gov.ph/jan-18- } \\
\text { 2017-speech-of- } \\
\text { president-rodrigo- } \\
\text { roa-duterte- } \\
\text { during-the- } \\
\text { 20th-founding- } \\
\text { anniversary-of-the- } \\
\text { premiere-medical- } \\
\text { center-daan-sarile/ }\end{array}$ & $\begin{array}{l}\text { https://www. } \\
\text { youtube. } \\
\text { com/watch? } \\
\text { v=2dkKghuTOOg }\end{array}$ \\
\hline
\end{tabular}




\begin{tabular}{|c|c|c|c|c|}
\hline $\begin{array}{l}\text { Jan. 19, } \\
2017\end{array}$ & $\begin{array}{l}\text { Philippine } \\
\text { National } \\
\text { Police (PNP) } \\
\text { oath-Taking }\end{array}$ & $\begin{array}{l}\text { Rizal Hall, } \\
\text { Malacañang } \\
\text { Palace }\end{array}$ & $\begin{array}{l}\text { http://pcoo. } \\
\text { gov.ph/jan-19- } \\
\text { 2017-speech- } \\
\text { of-president- } \\
\text { rodrigo-roa- } \\
\text { duterte-during- } \\
\text { the-philippine- } \\
\text { national-police- } \\
\text { pnp-oath-taking/ }\end{array}$ & $\begin{array}{l}\text { https://www. } \\
\text { youtube. } \\
\text { com/watch? } \\
\text { v=RPITCz1GVeg }\end{array}$ \\
\hline $\begin{array}{l}\text { Jan. 24, } \\
2017\end{array}$ & $\begin{array}{l}\text { Dialogue } \\
\text { with SAF } 44 \\
\text { families }\end{array}$ & $\begin{array}{l}\text { Heroes Hall, } \\
\text { Malacañang } \\
\text { Palace }\end{array}$ & $\begin{array}{l}\text { http://pcoo.gov. } \\
\text { ph/january-24- } \\
\text { 2017-speech- } \\
\text { of-president- } \\
\text { rodrigo-roa- } \\
\text { duterte-during- } \\
\text { his-meeting-with- } \\
\text { the-families-of- } \\
\text { the-special-action- } \\
\text { force-44-saf-44/ }\end{array}$ & $\begin{array}{l}\text { https://www. } \\
\text { youtube. } \\
\text { com/watch? } \\
\text { v=KGhPrHMFh5c }\end{array}$ \\
\hline Feb. 2, 2017 & $\begin{array}{l}\text { 38th National } \\
\text { Convention } \\
\text { of Philippine } \\
\text { Association of } \\
\text { Water Districts }\end{array}$ & $\begin{array}{l}\text { SMX Conven- } \\
\text { tion Center, } \\
\text { SM Lanang } \\
\text { Premier, La- } \\
\text { nang, Davao } \\
\text { City }\end{array}$ & $\begin{array}{l}\text { http://pcoo.gov. } \\
\text { ph/february-02- } \\
\text { 2017-speech- } \\
\text { of-president- } \\
\text { rodrigo-roa- } \\
\text { duterte-during- } \\
\text { the-38th-national- } \\
\text { convention- } \\
\text { of-philippine- } \\
\text { association-of- } \\
\text { water-districts/ }\end{array}$ & $\begin{array}{l}\text { https://www. } \\
\text { youtube. } \\
\text { com/watch? } \\
\text { v=CdScWhrOO-0 }\end{array}$ \\
\hline Feb. 3, 2017 & $\begin{array}{l}\text { Ceremonial } \\
\text { switch-on of } \\
\text { the M'lang } \\
\text { Solar Powered } \\
\text { Irrigation } \\
\text { System }\end{array}$ & $\begin{array}{l}\text { Barangay } \\
\text { New Janiuay, } \\
\text { M'lang, North } \\
\text { Cotabato }\end{array}$ & $\begin{array}{l}\text { http://pcoo.gov. } \\
\text { ph/february-03- } \\
\text { 2017-speech-of- } \\
\text { president-rodrigo- } \\
\text { roa-duterte- } \\
\text { during-the- } \\
\text { ceremonial-switch- } \\
\text { on-of-the-mlang- } \\
\text { solar-powered- } \\
\text { irrigation-system/ }\end{array}$ & $\begin{array}{l}\text { https://www. } \\
\text { youtube.com/ } \\
\text { watch ?v=J_ } \\
\text { Etfy6w2x8 }\end{array}$ \\
\hline
\end{tabular}




\begin{tabular}{|c|c|c|c|c|}
\hline Mar. 2, 2017 & $\begin{array}{l}\text { Induction of } \\
\text { newly elected } \\
\text { officers and } \\
\text { trustees for } \\
2017 \text { to } 2018 \\
\text { of the Cebu } \\
\text { Chamber of } \\
\text { Commerce } \\
\text { and Industry, } \\
\text { Inc. (CCCI) }\end{array}$ & $\begin{array}{l}\text { Gloria Maris } \\
\text { Room, Water- } \\
\text { front Hotel, } \\
\text { Mactan Island, } \\
\text { Lapu-Lapu } \\
\text { City }\end{array}$ & $\begin{array}{l}\text { http://pcoo.gov. } \\
\text { ph/march-02- } \\
\text { 2017-speech- } \\
\text { of-president- } \\
\text { rodrigo-roa- } \\
\text { duterte-during- } \\
\text { the-induction-of- } \\
\text { newly-elected- } \\
\text { officers-and- } \\
\text { trustees-for-2017- } \\
\text { to-2018-of-the- } \\
\text { cebu-chamber-of- } \\
\text { commerce-and- } \\
\text { industry-inc-ccci/ }\end{array}$ & $\begin{array}{l}\text { https://www. } \\
\text { youtube.com/ } \\
\text { watch ?v=bdQ_ } \\
\text { A7tZv-g }\end{array}$ \\
\hline Mar. 2, 2017 & $\begin{array}{l}\text { The Cebu- } \\
\text { Cordova Link } \\
\text { Expressway } \\
\text { (CCLEX) } \\
\text { groundbreak- } \\
\text { ing ceremony }\end{array}$ & $\begin{array}{l}\text { Virlo Public } \\
\text { Market, Km. } \\
\text { 30, Brgy. Dapi- } \\
\text { tan, Cordova, } \\
\text { Cebu }\end{array}$ & $\begin{array}{l}\text { http://pcoo.gov. } \\
\text { ph/march-02- } \\
\text { 2017-speech-of- } \\
\text { president-rodrigo- } \\
\text { roa-duterte- } \\
\text { during-the-cebu- } \\
\text { cordova-link- } \\
\text { expressway-cclex- } \\
\text { groundbreaking- } \\
\text { ceremony/ }\end{array}$ & $\begin{array}{l}\text { https://www. } \\
\text { youtube.com/ } \\
\text { watch ?v=pe- } \\
6 C T \_X J d s\end{array}$ \\
\hline $\begin{array}{l}\text { Mar. 14, } \\
2017\end{array}$ & $\begin{array}{l}\text { 1st General } \\
\text { Assembly of } \\
\text { League of } \\
\text { Municipalities } \\
\text { of the Philip- } \\
\text { pines }\end{array}$ & $\begin{array}{l}\text { Grand Ball- } \\
\text { room, Manila } \\
\text { Hotel }\end{array}$ & $\begin{array}{l}\text { http://pcoo.gov. } \\
\text { ph/march-14- } \\
\text { 2017-speech- } \\
\text { of-president- } \\
\text { duterte-at-the-1st- } \\
\text { general-assembly- } \\
\text { of-league-of- } \\
\text { municipalities-of- } \\
\text { the-philippines/ }\end{array}$ & $\begin{array}{l}\text { https://www. } \\
\text { youtube.com/ } \\
\text { watch ?v=jjqBJGq_ } \\
\text { XQg }\end{array}$ \\
\hline $\begin{array}{l}\text { Mar. 30, } \\
2017\end{array}$ & $\begin{array}{l}\text { Mass oath- } \\
\text { taking of } \\
\text { appointed } \\
\text { government } \\
\text { officials and } \\
\text { the Philippine } \\
\text { Councilors' } \\
\text { League }\end{array}$ & $\begin{array}{l}\text { Malacañang } \\
\text { Palace, Heroes } \\
\text { Hall }\end{array}$ & $\begin{array}{l}\text { http://pcoo.gov. } \\
\text { ph/march-30- } \\
\text { 2017-speech-of- } \\
\text { president-rodrigo- } \\
\text { roa-duterte- } \\
\text { during-the-mass- } \\
\text { oathtaking- } \\
\text { of-appointed- } \\
\text { officials-and- } \\
\text { the-philippine- } \\
\text { councilors-league/ }\end{array}$ & $\begin{array}{l}\text { https://www. } \\
\text { youtube.com/ } \\
\text { watch ?v=4r21- } \\
\text { udXjD4 }\end{array}$ \\
\hline
\end{tabular}




\begin{tabular}{|c|c|c|c|c|}
\hline $\begin{array}{l}\text { May 13, } \\
2017\end{array}$ & $\begin{array}{l}\text { Meeting with } \\
\text { the Filipino } \\
\text { community } \\
\text { In Hong } \\
\text { Kong Special } \\
\text { Administrative } \\
\text { Region }\end{array}$ & $\begin{array}{l}\text { Regal Airport } \\
\text { Hotel, Hong } \\
\text { Kong SAR }\end{array}$ & $\begin{array}{l}\text { http://pcoo. } \\
\text { gov.ph/may-13- } \\
\text { 2017-speech- } \\
\text { of-president- } \\
\text { rodrigo-roa- } \\
\text { duterte-during- } \\
\text { the-meeting- } \\
\text { with-the-filipino- } \\
\text { community-in- } \\
\text { hong-kong-special- } \\
\text { administrative- } \\
\text { region/ }\end{array}$ & $\begin{array}{l}\text { https://youtu.be/ } \\
\text { kOdl5bDcXOw }\end{array}$ \\
\hline
\end{tabular}

This study analyzes Duterte's rhetoric against the Church using a modified version of the dangerous speech framework of the U.S.-based Dangerous Speech Project (Benesch, 2013), which now counts among the methodological approaches recommended for researching hate speech, especially online (Stremlau \& Gagliardone, 2019).

Scholars have acknowledged the relationship between dangerous speech and hate speech in varying degrees. Kelechi Johnmary Ani, EbereFlorence Nnanwube, and Victor Ojakorotu (2019), who applied the dangerous speech framework in their study of both dangerous speech and hate speech in Nigeria, noted that while dangerous speeches "predispose individuals and groups to violence, hate speeches also raise concerns because of their dismissive and divisive capacity, and they could also trigger dangerous responses that could lead to eventual violence" (p. 12,417).

In particular, Benesch's framework deepens the analysis of harmful speeches by moving beyond text and giving equal emphasis to contextthe speaker, audience, sociohistorical environment, and the means of dissemination, "any or all of which can confer greater force on the speech act" (Leader \& Benesch, 2016, p. 77). Because of this, it is listed among the approaches that "add rigor to the process of identifying specific forms of speech" (Stremlau \& Gagliardone, 2019, p. 388)

The framework used in this study thus entails the scrutiny of the following elements in the rhetorical artifacts: (1) speaker, (2) content and its context, (3) the audience, (4) medium and (5) response. Guide questions from the Dangerous Speech Project ("What is Dangerous Speech,"n.d) pertaining to incidents of physical violence have been excluded from the checklist as they do not apply to the selected artifacts. 
Table 2. Hate Speech Framework Checklist ("What is Dangerous Speech," n.d.)

\begin{tabular}{|c|c|}
\hline Element & Guide Questions \\
\hline Speaker & $\begin{array}{l}\text { 1. Who is the speaker? What details about him make him influen- } \\
\text { tial in this context? } \\
\text { 2. Is he a respected political figure? Respected by whom, if so? } \\
\text { 3. Does he have some form of influence, control, or authority } \\
\text { over a particular audience? } \\
\text { 4. Is he a popular, charismatic, or particularly gifted public } \\
\text { speaker? }\end{array}$ \\
\hline $\begin{array}{l}\text { Content and } \\
\text { Context }\end{array}$ & $\begin{array}{l}\text { 1. What exactly about that content makes it hate speech? What } \\
\text { are the patterns or characteristics of speech that make it hate } \\
\text { speech, including major themes and key words? } \\
\text { 2. What are the roots of this conflict? } \\
\text { 3. Did the speech describe the target group as something else } \\
\text { other than humans? } \\
\text { 4. Did the speech suggest that the audience should feel hostile } \\
\text { toward the target group? Did it say that the audience suffered } \\
\text { harm or was likely to suffer harm in the hands of the target } \\
\text { group? } \\
\text { 5. Did the speech contain phrases, words, or coded language } \\
\text { that have taken on a special meaning in the understanding of } \\
\text { the speaker and audience? } \\
\text { 6. Did the speech give the impression that one or more members } \\
\text { of a target group might damage the reputation or integrity } \\
\text { of the audience group? Were members of the target group } \\
\text { compared to rotten apples that can spoil a whole barrel of } \\
\text { good apples, weeds that threaten crops, or stains on a dress or } \\
\text { the like? } \\
\text { 7. Did the speech suggest that women, girls, or children have } \\
\text { been defiled by members of a target group? } \\
\text { 8. Did the speech suggest to the audience group (the in-group) } \\
\text { not to be sympathetic to a target group? }\end{array}$ \\
\hline Audience & $\begin{array}{l}\text { 1. Who did this message reach? } \\
\text { 2. Was the speech directed primarily to members of the group it } \\
\text { purported to describe (the target group); to members of the } \\
\text { speaker's own group (the in-group); to both; or to someone } \\
\text { else? } \\
\text { 3. Is the audience experiencing fear or desperation? } \\
\text { 4. Does the audience have substantial or excessive respect for } \\
\text { authority, for reasons of culture, tradition, or identity? }\end{array}$ \\
\hline
\end{tabular}




\begin{tabular}{|c|c|}
\hline Medium & $\begin{array}{l}\text { 1. How was the speech act delivered, and how does that affect its } \\
\text { impact? } \\
\text { 2. If the speech was written, was it published in a media source } \\
\text { or website that is influential or respected, especially among } \\
\text { the intended audience? } \\
\text { 3. If spoken or posted publicly, was the location of the speech } \\
\text { particularly significant? } \\
\text { 4. Did the speech occur on or near a significant date, such as a } \\
\text { religious holiday or an anniversary of a significant past event? } \\
\text { Does the intended audience have access to and/or use alterna- } \\
\text { tive sources of information? }\end{array}$ \\
\hline Responses & $\begin{array}{l}\text { Supportive Responses: } \\
\text { 1. How did the audience react? } \\
\text { 2. Was the speech act liked/retweeted/shared on social media, or } \\
\text { praised by influential figures or media sources? } \\
\text { Opposition/Counterspeech } \\
\text { 1. Was the speech in question made known to the targeted } \\
\text { group or others who oppose the message? } \\
\text { Was there any response in opposition, such as negative re- } \\
\text { marks on social media, or public rebuke or admonishment by } \\
\text { influential figures or publications? }\end{array}$ \\
\hline
\end{tabular}

\section{Results and Discussion}

Speaker. This element provides personal and public information on Duterte which could explain how his speech act wields power and authority. Duterte, as the President, is expected to deliver speeches on various public occasions. His speeches bear implications on policies, both domestic and foreign. They form part of public records and are rich in archival value. The public takes its cue from him based on his speeches.

Duterte won the presidency on a platform that promised an end to lawlessness and graft and corruption in government ("Did Duterte keep or break his promises? A checklist," 2017). He enjoys high trust and satisfaction ratings from all sectors despite criticism on a number of his policies, including the war on drugs ("Second Quarter 2017 Social Weather Survey: Pres. Duterte's net satisfaction rating a new personal record-high of 'Very Good' +66," 2017; "June 2017 nationwide survey on the performance and trust ratings of the top Philippine government officials and key government institutions," 2017). He projected to voters the image that he was "being one of them"- unassuming and capable of crass, sexist, and self-deprecating humor. For example, in his August 31, 2016 speech, he said: "I considered one time in my life being a priest. Mabuti na lang hindi ako nasali...'di ngayon 
naging bakla na ako [It's good thing that didn't become one otherwise I'll be gay] (Presidential Communications Operations Office, 2016a).

Duterte's term as a local politico and his career as a lawyer provided him the training ground for public speaking. He proved his mettle as a charismatic speaker in the 2016 election when his campaign sorties drew a turnout that far outnumbered the audiences of his rivals, including the standard bearer of the ruling party ("Duterte Draws Huge Crowd in a Show of Force," 2016). His delivery style-rambling, folksy, seemingly random, and laced with expletives and jokes-was highly effective on the campaign trail. He carried on with the same style of public speaking as president. However, this manner of speaking has proven to be a liability because of the different expectations of how presidential speeches should be delivered.

Rhetorical resources are interchangeable with semiotic resources, whose main function is to convey meanings (Machin \& Mayr, 2012). Duterte employs rhetorical resources in his speeches that indicate his standpoint, agenda or ideology. Analysis of other elements of his speeches shows that he consciously deploys rhetorical resources ranging from linguistic to nonlinguistic resources such as word, images, sound, symbols, and bearing.

Content and Context. Duterte had attacked the personal dignity of members of the clergy, dehumanized the Roman Catholic Church, imputed crimes against its leaders, incited discrimination against priests, drove a social wedge between the Church and its followers, and even advocated violence against priests.

Duterte's unrestrained attacks against the Church are framed around the very thing which gives the institution its force: morality. He took pains to convince the audience of his speeches that such virtue has been corroded, mainly because the Church has grown rich and corrupt, uncaring and lecherous, as evidenced by the stories in Rufo's Altar of Secrets (2013).

Duterte cast aspersions not only on the Roman Catholic Church as an institution but also on its leaders. The supposed lack of moral ascendancy and hypocrisy of bishops and priests in general were constant themes in nine of his speeches. Specifically, the president singled out two bishops, Davao Archbishop Fernando Capalla and Novaliches Bishop Emeritus Teodoro Bacani, for moral decadence, accusing them of keeping mistresses or wives.

Addressing police officers in Zamboanga City on Oct. 10, 2016, the president said, "Sila Capalla, 'yung bishop naming doon. Kung mag . . . pareho kami, may mga kabit din sila. Sila Obispo, ako meron noon Mga pari $\mathrm{p}^{* * * * * * * i n a . ~ B w i s i t . ~ M g a ~ p a ~ m o r a l-m o r a l ~ n a " ~[C a p a l l a, ~ o u r ~ b i s h o p, ~ a n d ~}$ I are alike. Both of us have mistresses. The priests, son of a whore. They're a nuisance. And they pretend to be moral] (RTV Malacañang, 2016, 8:32). 
In his January 24, 2017 message to the families of the 44 members of the elite Special Action Force killed in an encounter with Muslim insurgents in Maguindanao on January 2015, Duterte said:

"Basahin ninyo 'yang libro na 'yan. Ang opening remark si Bacani. P*:**** $\mathrm{i}^{* * *}$ Bacani na 'yan, dalawa pala ang asawa. Pareho ko. Parang mayor rin ang buang. ..." [Read the book (Altar of Secrets). The opening remark is Bacani. Son of a whore. This Bacani, turns out that he has two wives. Just like me. He is like a mayor, this lunatic.] (Presidential Communications Operations Office, 2017b, para. 98)

Four of Duterte's speeches went to the extreme of ascribing subhuman or nonhuman characteristics to the Church, its leaders, or followers. For example, the President said in his Jan. 24, 2017 speech: "Tapos kung magsalita itong mga unggoy na ito" [And when these priests talk, these monkeys] (Presidential Communications Operations Office, 2017b). In two speeches he delivered on March 2, 2017 in Cebu, first before businessmen and then at the groundbreaking of an expressway, Duterte called Catholics "yawa" or the devil (Presidential Communications Operations Office, 2017f). By this study's count, the president has used the term "yawa" 15 times in his speeches, including at a big Christmas gathering of barangay officials in his hometown.

The President alternately accused the Roman Catholic Church and its members of the crimes of sexual molestation and graft and corruption in eight speeches. When discussing the sexual harassment inflicted by priests, he adjudged all of them guilty. Recalling his years as a pupil at the Jesuit-run Ateneo de Davao during the oathtaking of Philippine National Police (PNP) officers in Malacañang on Jan. 19, 2017, Duterte said:

When we were making confessions to you, we were being molested, hinahawakan na kami [They were fondling us] ... If you cannot mend your ways, if you cannot even give justice to the, you know, the small boys that you have molested in the past, you do not have that moral ascendancy to lecture on what to do. (Presidential Communications Operations Office, 2017a, para. 22)

In the same speech, he brought up the luxurious vans then-President Gloria Arroyo was said to have distributed to some Church leaders. He said:

Kayong mga pari, remember you ask mga sasakyan kay Gloria? Knowing fully well that mga pulis nga walang masakyan. Kayo de Pajero pa, mga $\mathrm{p}^{* * * \cdots * * * * \mathrm{i}^{* * * * *}}$ kayo. Binigyan 
kayo knowing that there is a principle of separation between the Church and State. It was sheerly, purely graft and corruption because you do not deserve it [You priests, remember that you asked for vehicles from President Gloria Macapagal-Arroyo? Knowing fully well that the police have no vehicles. But you have Pajeros, you sons of a whore. You were given despite the principle of separation between the Church and the State. It was sheerly, purely graft and corruption because you do not deserve it]. (Presidential Communications Operations Office. (2017a, para. 44)

Several of the President's speeches showed his open contempt for gays, especially in relation to the priesthood. On Aug. 31, 2016, the president told members of the Davao City-based Jesus Anointed One Church this: "Grabe yung homosexuality ... silang lahat may tama" [The priests' homosexuality is terrible ... they are all into it] (Presidential Communications Operations Office, 2016a, para. 51). And he added:

I was considering, 'nong sa college ako, mga second semester sa-I was, I asked my permission from my mother, kasi yung challenge ng trabaho ng pari. I considered one time in my life being a priest. Mabuti't na lang hindi ako nasali, 'di ngayon naging bakla na ako [I considered becoming a priest when I was in college, during the second semester. I asked my mother's permission because of the challenges of priesthood. I considered at one time in my life of being a priest. It's a good thing I didn't join the priesthood or I'd be gay now]. (para. 51)

Attempts to not only create a wedge between Catholics and the Church but also lure them away from their faith were evident in 10 speeches analyzed by this study. Following are examples of Duterte charging the Church and its bishops with enriching themselves from money they collected from their flock, disregarding the plight of the poor, and leading ostentatious lives:

Jan. 19, 2017: With all the pageantry and ceremony, pa gold-gold pa kayo ng mga chalice dyan. Eh samantala ang nakikinig sa inyo mga walang kain. Mga chalice-chalice pa kayo, de-gold pa [You kept on ranting, with all the pageantry and ceremony, you have gold chalices. While those listening are hungry. You have chalices and they are made of gold]. (Presidential Communications Operations Office. (2017a, para. 66) 
Feb. 2, 2017: Kita ninyong kaugok ninyo. You refuse to what? To bless? Mamatay na lang ako, galit ka pa, magbayad pa ako sa $\mathrm{p}^{* * * * * * * *} \mathrm{i}^{* * *}$ ninyo, ay susmaryosep [Such stupidity. You refuse to bless the dead? I'm about to die, you get angry and demand that I pay first. Son of a whore. Jesus, Mary, Joseph]. (Presidential Communications Operations Office, 2017c, para. 97)

He offered the Catholics his way out:

Aug. 31, 2016: Sa Luneta, miting de avance. Sabi ko: Okay. Let this be a referendum. Me against the bishops. Pati cardinal kasali. Sige, kayong lahat Katoliko na gusto pumunta ng langit, sumabay kay bishop na 'yan. Kayong gusto sa impyerno, sumabay kayo sa akin [Let me repeat what I said at the final rally before the election at Luneta: Let this be a referendum: me against the bishops and even the cardinal. All you Catholics who want to ascend to heaven, follow the bishop. Those of you who wish to go to hell, follow me]. (Presidential Communications Operations Office. 2016a, para. 54)

Dec. 27, 2016: Naay bag-o ana, Iglesia ni Duterte, way bawal. Limang asawa, pwede ra. [There is a new one, the Church of Duterte, no prohibitions. Five wives, it is fine.] (Presidential Communications Operations Office. 2016b, para. 48)

Duterte broadly hinted of violence against the Church and priests on at least three occasions. After making a pitch in his Aug. 31, 2016 speech for the book Altar of Secrets, he said, "Don't read it because you will kill all the priests. Talks about misconduct, sex and everything" (Presidential Communications Operations Office. 2016b, para. 49). His Dec. 27, 2016 speech, delivered in Cebuano language, also planted the idea of violence against priests:

Look around, look at Midsayap, the priest there who said the mass was always ranting extrajudicial killing then a grenade was lobbed at them, I asked the police, I asked the NPA there, who did it, Sir, drugs. These priests. You'll be the next to have a grenade thrown at you, the drug dealers, tell the priests to catch it, or throw it a them, here, catch it. (Presidential Communications Operations Office. 2016b, para. 26) 
Duterte was referring to Midsayap, a town in Mindanao, and the New People's Army (NPA), the armed wing of the Communist Party of the Philippines (CPP). His March 2, 2017 speech in Cebu justified the destruction of churches: "It is your karma when your churches got destroyed. You know why God destroy the churches? To show you that you are not deserving of his mercy" (Presidential Communications Operations Office. 2017f, para. 19). A 7.2-magnitude earthquake in 2013 destroyed historic Catholic churches in Cebu and Bohol provinces ("Death Toll Rises to 97; Bohol Hit Hard," 2013).

It is significant to note that many of Duterte's accusations were nothing new in the almost-500-year history of Catholicism in the country. What is new is the studied capacity of Duterte to crystallize the discontent, provide new anecdotes to fuel the recirculation of past accusations, and reinforce his "us vs. them" trope. He even resorted to false or misleading claims in his speeches in an obvious bid to persuade his audiences to turn against the Church. "Muingon ka na Duterte kay killer. Kay kamo, unsa may diay mo? Killer, kamo gani gapatay kay Kristo ... Ay pangita mog laing relihiyon" [You (bishops and priests) say that Duterte is a killer, What about you? What are you? Killer! You killed Christ... Go look for another religion] (Presidential Communications Operations Office, 2016b, para. 45,46) he said on Dec. 27, slamming the Church's opposition to his war on drugs that had by then left thousands of people dead by using a lie - the Roman authorities led by Pontius Pilate, not the Roman Catholic Church, executed Christ following the clamor of the Jews and their religious leaders. Duterte also twisted the facts stated in Altar of Secrets by accusing Bacani of having two wives when the book only said that he had been accused of molesting his secretary (Presidential Communications Operations Office, 2017b). This led Bacani in a January 26, 2017 radio interview to jokingly offer a Php 10 million reward if the President could prove he has two wives. The bishop said: "Huwag niyang lalabanan ang katotohanan sa pamamagitan ng kasinungalingan at paninira ng kapwa. Maghunos-dili naman siya. Presidente siya, hindi naman ordinaryong tsismoso" [He shouldn't fight the truth with lies and character assassination. He should exercise restraint. He is the president, not an ordinary gossip] ("Bishop dares Duterte: Produce my 2 wives, I'll pay you P10M," 2017).

On the surface, the President appears to have retained the delivery style that made him popular when he was on the campaign trail—rambling, folksy, seemingly random, and laced with expletives and jokes. But a closer scrutiny of his anti-Church diatribes points to a palpable pattern, especially during the six occasions he brought up Rufo's book. "By listening to what he (Duterte) says, one can reconstruct a consistent narrative. $\mathrm{He}$ is ultimately responsible for what he says and does," then-presidential 
spokesperson Ernesto Abella (as cited in Maslog, 2017, p. 30) said in a forum in 2016, during which he explained how to deconstruct and understand the president's statements.

The "script" or repertoire the president follows when attacking the Church begins with discarding or deviating from a prepared speech. $\mathrm{He}$ would rant without fail about how priests and bishops are corrupt sex offenders who get rich at the expense of the faithful and who are uncaring of the poor and drug users. Then, at the close of the five-to-fifteen-minute harangue, he would introduce the Altar of Secrets and urge his audience to find it online and read about the skeletons in the Church's closet. An aide, at times his then-Special Assistant (now Senator) Christopher "Bong" Go, would be summoned to bring him a copy of the book. The President occasionally capped his speech by giving away copies. Duterte mentioned Rufo's book for the first time on Aug. 31, 2016: "I will end this talk by just suggesting that there is a book. It's online. The title is 'Altar (of) Secrets.' Tingan mo sa ... Tingnan mo ngayon [Look for it now]. 'Altar [of] Secrets.' 'Secrets of the Altar,' 'ika nga [as you'd say]...It's online. You can buy it" (Presidential Communications Operations Office, 2016a, para. 52).

The curses that form a perennial element in the president's speeches are a mix of eschatological and scatological terms delivered in English, Tagalog, and Cebuano. His anti-Church comments showed that he is obsessed with eschatological fantasies-hell, devil, death, purgatory and heaven, terms that he easily mixed with "muck" ("whore" and "shit," for example).

In terms of context, Duterte's hostile sentiments toward the Church were apparently borne out of two things: first, the Church's criticism of his human rights record over the policy on drugs, and second, by his own account, his experience of sexual harassment in the hands of an American priest.

Duterte never hid his contempt for the Church when, as a mayor, his administration was criticized by Bishop Capalla for its seeming tolerance of the so-called Davao Death Squad that were behind the killing of drug suspects and thieves (Arguillas, 2016).

In three of the thirteen speeches, Duterte also alluded to his being a victim of sexual harassment, in the form of groping by a priest when he was in grade school. In one of his speeches, he even named the Jesuit priest responsible: the late Fr. Mark Falvey. ${ }^{1}$ Sometimes, while speaking, he would call on a former schoolmate, Finance Secretary Carlos "Sonny" Dominguez, to confirm his account. For example, in his May 13 speech before migrant workers in Hong Kong, Duterte said: "Sa Ateneo 'di ba every Friday mass 'yan tapos you are mag-communion ka. Totoo 'yan Sonny, kami nga doon hinihipo kami ng pari. .. . Totoo 'yan. Hinihipo kami ng pari” [In Ateneo 
isn't it that we have mass every Friday then you receive communion? That's true, Sonny, we were groped by a priest. That's true. We were groped by a priest] (Presidential Communications Operations Office, 2017g, para. 146). There is no evidence, however, that Duterte's accusations have reached the courts or a Church investigating body.

Several events preceded the President's vitriol on the Roman Catholic Church. The Church has been one of the most vocal critics against several of Duterte's policies, especially the deadly antidrug campaign he started as soon as he sat in office and his decision to allow the burial of the late strongman Ferdinand Marcos at the Libingan ng mga Bayani on Nov. 18, 2016 with full military honors (Santos, 2016). The Catholic Bishops' Conference of the Philippines (CBCP), which has more than a hundred prelates as members, issued a statement calling Marcos' burial "an insult to the EDSA spirit" and a mockery of the Filipinos' fight for democracy (Tan, 2016). The President's Dec. 27, 2016 speech came days after the Redemptorist Church in Baclaran had mounted a photo exhibit on the victims of extrajudicial killings (EJKs) during the nine-day Simbang Gabi (Dawn Masses) preceding Christmas (Sauler, 2016).

The president's tirades from Jan. 19, 2017 onwards followed a message delivered by Bacani at the Fourth World Apostolic Congress on Mercy in Batangas, calling Duterte's anti-drug strategy of tokhang a "bringer of death" ("No limit to the Divine Mercy - Bishop Bacani," 2017). Tokhang is a Cebuano portmanteau for "knock-and-plead," where the police visits the homes of drug users to ask them to surrender. The phrase became a shorthand for Duterte's violent antidrug campaign. But Duterte escalated his antiChurch tirades after the CBCP issued on Jan. 30, 2017 its first pastoral letter condemning the killings resulting from the antidrug campaign ("Killings Must End Now, Says CBCP Head," 2017). The 946-word letter expressed concern over what the bishops called the "reign of terror" in many places where the poor live, and the indifference of many to the wrongful acts.

On Jan. 30 as well, the CBCP issued another pastoral letter urging its flock to be vigilant about moves in Congress to amend the Constitution and laws in order to reinstate capital punishment and to lower the age of criminal liability ("CBCP Pastoral Statement on Death Penalty," 2017). The legislative proposals carried presidential imprimatur.

One of Duterte's fiercest attacks on the Church was during his Feb. 3, 2017 speech when he said:

Ang ayaw ko sa pari, ayaw ko ng Katoliko, hipokrito. Huwag mong gawin 'yan, huwag mong gawin 'yan, kung ako ang maggawa okay lang. Sigeg sermon, sigeg sermon sa pulpito 
gida atake ko. Anong mga ginagawa ko para man ito sa bayan ko. Kaya pinapatay ko 'yung tao, anak ng-400... Four million drug addicts. Four million slaves, slaves sa kwarta, sa bulsa, sa drug lords [I don't like priests, I don't like the Catholics. Hypocrites. They keep saying don't do this, but it's okay for me. They keep delivering sermons, from the pulpit they attack me. Whatever I do is for the country. That's why I have them killed. Four million drug addicts means four million slaves to money, in the pockets of the drug lords]. (Presidential Communications Operations Office, 2017d, para. 58-59)

In early January 2017, Francisco Tatad, a former senator and a member of the Opus Dei, an institution under the Roman Catholic Church, wrote in his newspaper column that Duterte might have sought medical treatment for cancer in China during the New Year (Tatad, 2017). Duterte would rake this issue up in his speech in Cebu two months later, on March 2, 2017 a day after Ash Wednesday, a major Catholic observance in which churchgoers mark the start of Lenten season. Duterte used caustic words and referred to a private body part to attack Tatad and the Opus Dei (Presidential Communications Operations Office, 2017f).

Audience. The lexical map that defines the territory of Duterte's antiChurch rhetoric within the 13 speeches analyzed appears to be a narrow one in terms of audiences, geography, and political boundaries. He delivered his anti-Church speeches mostly in what are considered his strongholds and before preferred audiences. Other than Malacañang Palace, where three of the 13 speeches covered by this study were delivered, and Nueva Ecija where he delivered a speech on January 18, 2017 all the venues were in cities and provinces where he won by a wide margin in the 2016 Elections. Mindanao was the location of five speeches, three of which were delivered in Davao City where Duterte held sway as mayor for more than 22 years. Two speeches took place in Cebu, where his father Vicente, a native of southern Cebu, was once a local official. The Dutertes only migrated to Davao in 1949.

Speeches are often tailored for certain audience, and Duterte's presidential speeches are no exception. In terms of choice of audience, the military, local government officials, and public utilities employees come out as his preferred audience. The speeches he made before the PNP are noteworthy, especially the one on Jan. 19: It was the oathtaking of newly appointed police officials. His audience consisted of officers of the law enforcement agency that has been leading the antidrug war and that has 
come under fire from various groups for the extrajudicial killings and human rights violations.

The kinds of audience he chooses also represent the groups that he is used to facing in his more than two decades of being mayor of Davao City. This means that he is generally familiar with the issues they are facing and probably the "language" that they speak. So he is able to dispense with coherence, a basic element of formal speeches. This is evident in the way that he strung arguments and mentioned individuals in his October 10, 2016 speech before law enforcers in Mindanao:

Kaya kung hindi pa sabihin mo na, 'akin ito', 'abuso ko lang ito'. What for? Why should I kill my countrymen? Kaya kung sa itong mga ... Sila Capalla, 'yung bishop namin doon. Kung mag . . . Pareho man kami may mga kabit rin. Sila obispo, ako, mayor noon. Mga pari. $\mathrm{P}^{* * * * * * * *}$ ina. Bwisit. Mga pa-moral-moral na. Papaano ko pigilan 'yan? Mag-pigil ako ngayon? Patay ang Pilipinas [If they didn't say, 'this is mine,' 'I've abused it.' What for? Why should I kill my countrymen? That's why these ... Those . . Capalla, our former bishop, when he ... We are just alike; we have mistresses. They were the bishops then; I was the mayor. Priests. Sons of a whore. Annoying. They pretend to be moral. How can I stop that? I'll stop now? The Philippines will be dead]. (RTV Malacañang, 2016, 8:24)

From the excerpt one could notice that the words "kill," "death" and "dying" framed the anti-Church arguments. They key words are by no means accidental. In fact, they convey the uncertainties faced by the military in that area fighting the Abu Sayyaf. Thus, Duterte's lexical choices, while not governed by formal rhetorical strategies, use unexpected conventions with a specific political effect-to sow fear. The Church that preaches afterlife is dismissed as uncaring. In all, even if they appear to be too casual for a presidential speech, a close look at Duterte's lexical choices show that he selects from a range of word choices to fortify his rhetoric.

The President also resorts to a mix of English and Filipino in addressing his audiences. On two occasions, on Dec. 27, 2016 in Davao City and on March 2, 2017 in Cordova, Cebu, he spoke mostly in Cebuano, a language widely spoken in Visayas and Mindanao ("Mindanao Comprised About 24 Percent of the Philippines' Total Population," 2005). The use of Cebuano before a huge crowd of barangay officials indicates a level of informality and familiarity. This is the same tactic he uses in his speeches before mayors and councilors. 
As for the semiotic choice of the speaker, Duterte's stand against the Church is always communicated before audiences that are less likely to contest the issue in a critical and rational manner. In other words, they are not the main interlocutors of the Church's doctrine, missions, history, and obligations. While they laughed at hearing the curses directed at the Church and clergy, these audiences would not bother with complex issues surrounding the Roman Catholic Church.

Response. Duterte's folksy, off-the-cuff speeches often leave his audience in stitches or draw hearty applause. This is also the effect in majority of the speeches where he demonizes the Roman Catholic Church.

This study tracked 58 instances when his audiences laughed and a dozen instances when they applauded as the President blasted the Church. These instances happened the most at the Dec. 27, 2016 Christmas gathering of barangay officials in Davao City even as the official transcript of the PCOO reflected no criticism against the Church. ${ }^{2}$ Overseas workers in Hong Kong (May 13, 2017), town mayors at the Manila Hotel (March 14, 2017), and pastors and members of a non-Catholic evangelical group in Davao City (Aug. 31, 2016) also broke into laughter more than 10 times over the President's negative comments about the Church.

Of the 13 speeches, only three did not elicit laughter or applause. Although his attack on the Church was lengthy at the Jan. 19, 2017 oathtaking of PNP officials, the audience did not break out into laughter or applause. However, the video showed the PNP officials, led by then-Director General Ronald de la Rosa, obviously pleased. The footage of the Oct. 10, 2016 event also showed PNP officials led by De la Rosa in a similar mood when the President was lambasting the Church.

Top government officials apparently took their cue from Duterte and started criticizing the Church for speaking against the drug war, human rights violations. and the proposed reinstatement of death penalty. After the CBCP's Jan. 30, 2017 pastoral letters and statements and Duterte's Feb. 2 and 3, 2017 speeches, members of his Cabinet and his other allies in government began borrowing a page from his play book. Among those who began to openly criticize the Church was PNP's De la Rosa, whose officers and men had been roundly criticized by the Church for the death toll arising from the antidrug campaign. On Feb. 5, 2017 de la Rosa told journalists:

"Anong gusto nila, pabayaan na lang namin ang problema sa drugs? [What do they want, that we neglect the drug problem?] You know, please tell them I can communicate with God without passing through them." He added, "Bakit, masabi mo ba "yung Church, pari mismo they are 
perfect? Wala silang ginagawang kalokohan? Hindi ko sila inakusahan but my relationship to God is direkta pa [Why? Can the Church and the priests say they're perfect? That they're clean? I'm not accusing them but my relationship with God is direct])" (De Jesus, 2017, para. 2).

Then Interior Secretary Ismael Sueno slammed the Catholic Church for supposedly failing to guide the people away from crime and illegal drugs ("Kayo Ang May Sala: Sueno Says Church Failed to Shepherd Flock From Drugs," 2017). "The Church failed in shepherding its flock. There is also blame on the Church" (para. 2), he said.

Also on Feb. 5, then Speaker Pantaleon Alvarez called Church officials "a bunch of shameless hypocrites" (Aurelio, Ramos, \& Nonato, 2017, para. 2). "Sinner as they are, the Catholic Church has no moral ascendancy to judge what is right and wrong" (para. 2), he said. Days earlier, Alvarez, in an interview with TV5 Reaksyon, echoed Duterte's sentiments toward the Church after the Church assailed the bill seeking to reimpose capital punishment. Alvarez said:

Itong Simbahang Katoliko, panay object ng object, pag may nangyaring heinous crimes, wala naman silang ginagawang tulong doon sa mga biktima. In fact pati yung biktima nga, hindi pa ililibing iyan, hindi pa nila bebendisyunan iyan kung hindi pa magbabayad. Sana, kung hindi tayo makakatulong, ay huwag na lang tayong maging hadlang pa para mabigyan ng solusyon yung problema ng ating bayan [The Catholic Church keeps objecting (to the reinstatement of the death penalty). But if heinous crimes happen, they don't lift a finger to help the victims. In fact, the victims can be buried because the Church won't give benediction unless they've paid. If you (the Church) can't help, don't be an obstacle so we can find a solution to the country's problem] ("Alvarez slags Catholic Church anew: Bayad daw muna bago bendisyon," 2017, para. 3).

Presidential daughter and Davao City Mayor Sara Duterte-Carpio took a similar stance and lashed back at former CBCP President Socrates Villegas who had said her father had "singlehandedly defaced the memory" of the 1986 EDSA Revolution. Villegas was alluding to Marcos' burial at the Libingan ng mga Bayani but Duterte-Carpio called the bishop and his "group" a "bunch of delusional hypocrites" "Sara Duterte to Villegas: You are worse than a hundred President Dutertes," 2017, para. 5). 
Medium. Duterte's speeches qualify as public speech acts for three reasons. First, they are mostly delivered in public gatherings. Second, they cover a range of issues that are of public interest. While it is true that some of his messages were delivered during private occasions, such as the gathering of the non-Catholic Christian group The Jesus Anointed One Group (Aug. $31,2016)$, the anniversary of the privately owned Premier Medical Center (Jan. 18, 2017), and the induction of the officers of the Cebu Chamber of Commerce and Industry (March 2, 2017), the speeches also discuss diverse national and political issues. For example, his Aug. 31, 2016 speech was not confined to concerns of his immediate audience: church ministers attending their annual enrichment program.

Third, his speeches acquire a public nature because they are accessible through various channels. As president, Duterte has at his disposal a wide array of media outlets that operate directly under the PCOO: Philippine Information Agency (PIA), Philippine News Agency (PNA), Radio Television Malacañang (RTVM), People's Television Network (PTV), Bureau of Broadcast Services (BBS, which includes Radyo ng Bayan and its more than 30 radio stations and some 20 affiliate radio stations), and the Intercontinental Broadcasting Corp. (IBC). Many of his speeches are broadcast live over state radio or TV, or both. All speeches-the transcripts, audios, and videos-are made available to the public through the PCOO website. The videos are even hosted on YouTube, and his speeches form the bases for a substantial number of press releases produced by the PCOO.

The PCOO and the offices it supervises maintain a strong social media presence. On May 2017, the president appointed blogger and supporter Mocha Uson, who has more than five million followers on Facebook, as PCOO assistant secretary in charge of social media ${ }^{3}$ (Lagrimas, 2018)

Many events the President attends are open to media that consist of reporters from different platforms, including bloggers. Some of these bloggers broadcast his speeches live, either excerpts of these or in toto. They turn the President's speeches into news accounts.

The President enjoys massive following on social media that dates back to the election period. He was swept to power with the help of volunteer and paid keyboard warriors and trolls who galvanized support for him and flayed his political rivals. Duterte's official Facebook page (https://www. facebook.com/rodyduterte/) has more than four million followers. It is no surprise then that Duterte's hostility toward the Roman Catholic Church has been reiterated and amplified the most through social media via partisan accounts on YouTube and Facebook. His followers on social media, would even exceed the hate spin he resorted to, ascribing to priests attributes not mentioned in the presidential rhetoric such as "rapist." 
Three pro-Duterte bloggers with sizable following emerged to be the most vocal against the Church: Mocha Uson (Mocha Uson Blog, https:// www.facebook.com/Mochablogger), RJ Nieto ${ }^{4}$ (Thinking Pinoy, https:// www.facebook.com/TheThinkingPinoy), and Sass Rogando Sasot (For the Motherland, https://www.facebook.com/forthemotherlandph).In her Dec. 6 column, Uson (2017a) broached the idea that the CBCP was "anti-Christ" for refusing to forgive Marcos and claimed the Church was "encouraging hate and anger toward a dead person."

Uson used her blog to share anti-Church posts from the President's supporters. These include a meme she posted on Feb. 19, 2017 showing the photo of Church leaders and the caption "How can a Church own a school but don't allow the poor to attend it?"-an apparent attempt to drive a wedge between the Church and poor Filipinos, a common theme in the presidential polemic against the Church.

In his "Duterte vs CBCP" post on YouTube on Jan. 21, Nieto, who has more than one million Facebook followers, amplified Duterte's message that the Church is rich yet has done nothing for the poor and the antidrug campaign (Oplan Tokhang, 2017). Adding that the Manila archdiocese has billions of pesos worth of stocks with a private bank and that the Zamboanga and Nueva Segovia archdioceses hold considerable stocks in a financial institution he did not name, Nieto further taunted the Church: "How difficult is it for the Church to donate P1 billion?" (Oplan Tokhang, 2017).

In a post, Sasot (2017) challenged the Church: "Asaan iyong concern ninyo sa 'reign of terror' noong ang naghaharia-harian sa lugar ng sinasabi ninyong 'places of the poor' eh mga drug pushers at syndicates? At ikalawa, asaan ang pag-condemn sa mga drug cartels at mga government protectors nila?" [Where were you when drug lords were lording it over in places of the poor where there is reign of terror? Why did you not condemn the drug cartels and their government protectors.] (para. 1).

\section{Counterspeech}

In its response to the presidential rhetoric, the Roman Catholic Church tried to avoid referring to Duterte, the individual, in favor of sticking to the government's questionable policies. But it was not successful all the time, especially for the bishops who had been singled out by the President.

The CBCP Media Office maintains a website (http://cbcponline.net/ $\mathrm{ph} /$ ) and a Facebook page (https://www.facebook.com/cbcpnews/) with 353,777 followers as of mid-2017. The bishops tried to counter Duterte by pointing out the inaccuracies of his claims and his deflections of criticisms on his tokhang-related human rights abuses ("Faithful urged: Support 
CBCP stand on issues," 2017). They also organized events to rally Catholics to their cause. Responding to the president's Jan. 19, 2017 criticism, Lipa Archbishop Ramon Arguelles acknowledged the Church has imperfections but will continue teaching the gospel of life ("Church will not be Silent, Amid Killings” 2017). A day after Duterte delivered his Jan. 24, 2017 speech, Bacani, whom Duterte singled out as having two wives, said he would not back down from calling out wrong policies and programs of the government and urged the bishops to speak as one (Tenedero, 2017).

Two days later, on January 26, 2017, Mindanao priest and peace advocate Eliseo "Jun" Mercado," in an open letter posted on his Facebook account, urged Duterte to stop bullying the Catholic Church:

President Digong, we have known each other for years, and we are both from Mindanao ... in the name of God; and in the name of all that our mothers held sacred; no matter our bitter and painful experiences; I ask you; I appeal to you; and I beg you ... STOP BULLYING THE CATHOLIC CHURCH" ("Mindanao Priest to Duterte: Stop Bullying Catholic Church," 2017).

This appeal to their affinity, being both residents of Mindanao, has had no effect on the subsequent speeches of Duterte. The Church has also tried to exercise its moral authority over Duterte but was ignored.

Given Duterte's popularity, the bishops appear cautious in their public statements. For example, Reacting to Duterte's Feb. 2 and Feb. 32017 antiChurch statements, Villegas told a newspaper forum: "Unfortunately, it was taken in that context. It was taken negatively. I was hoping for a position that would say 'let's dialogue' because today, there is nothing that we cannot do if we dialogue and work together. So I was hoping for that" "Malacañang, Allies Outburst," 2017). Villegas also clarified that the pastoral letter released did not make any reference to Malacañang but was addressed to the people of God.

Unlike Duterte's organized events, attendance to Church activities has been modest. On Feb. 17, 2017, followers of the Catholic Church faithful and other churches joined Walk for Life, a pre-drawn prayer rally seeking an end to EJKs ("Killings Must End Now, Says CBCP Head," 2017). About 20,000 were said to have come from 21 Catholic dioceses in Luzon and from other Christian churches. Other Church leaders and groups have chosen to keep quiet. There were no counterspeeches from the Church, Opus Dei, or Tatad himself to the president's March 2 attack. 


\section{Conclusion}

This study concludes that Duterte's anti-Church statements constitute a form of hate speech. The absence of law on hate speech in the country and the remoteness of its construction from forms of hate speech in other countries, though, do not absolve Duterte's rhetoric from that verdict. His statements cannot be reduced to mere irrational forms of argumentation in the spirit of deliberative democracy. His anti-Church narratives, which he justified as driven by his duty to instantiate the public good, were in fact hateful language to defend his vicious carceral policies as seen through his antidrug campaign and social programs. From the limited content analysis of his speeches and the examination of the rhetorical resources he used, we conclude that the claims and the speech acts are forms of hate speech that attack personal dignity, dehumanize groups, incite discrimination, advocate hostility, create social wedge, and impute a crime. By invoking the mandate to protect his country, his people, and the poor, Duterte has foisted his moral authority that feeds on the public's insecurities and fears, reminiscent of Cohen's (1972) "moral panic." It is not that such issues are nonexistent but they, like child abuse and pedophilia, are extrapolated and blamed wholly on one sector-the clergy.

Duterte's constant vilification of the Catholic Church, its clergy, doctrines, and sacraments, complete with invectives such as "corrupt," "devil" and "son of a whore," has sustained public anxieties. Then his rhetoric takes a moral turn to question the charity and integrity of the Church. What operates, in a condition of moral panics, is resonance or some form of identification between the audience and the one who delivers the speech, in this case, Duterte. This rhetorical ploy conveys a necessity of cleaning up a broken institution.

The country does not have a law penalizing hate speech or a law criminalizing group libel, but for lawyer Romel Bagares (personal communication, August 31, 2017), President Duterte, who wields "awesome powers in his office ... runs the risk of chilling the speech of his target, in this case, the Church." While the Church may not be cowed by virulent statements, Bagares said Duterte has to be reminded of the effects of his speech acts, "considering that the freedom of religious occupies the higher rungs of constitutional rights in the Philippines."

In all, presidential speeches are important because they may be rendered into state policy. Thus, they should always convey respect and dignity rather than unqualified hatred that is actually damaging to society. For this reason, presidential speeches must be nonmanipulative, transparent. and mindful of reciprocal respect. 


\section{References}

Alvarez slags Catholic Church anew: Bayad daw muna bago bendisyon. (2017, February 2) Retrieved from http://politics.com.ph/alvarez-slags-catholic-church-anew-bayad-daw-muna-bago-bendisyon/

Amnesty International (2017). "If you are poor, you are killed": Extrajudicial executions in the Philippines' "War on drugs." Retrieved from https://www.amnestyusa.org/files/philippines_ejk_report_v19_ final_0.pdf

Ani, K., Nnanwube, E., \& Ojakorotu V. (2019). An evaluation of the concepts of dangerous and hate speeches, and their security implications in the social media era Nigeria. Gender and Behaviour, 17(1), 12417-12428. Retrieved from https://www.ajol.info/index.php/gab/article/view/186760

Arguilas. C. O. (2016, October 8). Davao's archbishop emeritus to Duterte: "Listen." Minda News. Retrieved from http://www.mindanews.com/top-stories/2016/10/davaos-archbishop-emeritus-to-dutertelisten

Aries, Rufo. (2013). Altar of secrets: Sex, politics and money in the Philippine Catholic Church. Manila: Journalism for Nation Building Foundation.

Aurelio, J. M., Ramos, M., \& Nonato, V. F. (2017, February 6). House Speaker calls bishops hypocrites. Inquirer.net. Retrieved from http://newsinfo.inquirer.net/868480/house-speaker-calls-bishopshypocrites

Benesch, S. (2013, February 23). Dangerous speech: A proposal to prevent group violence. Dangerous speech project. Retrieved from https://dangerousspeech.org/guidelines/

Bishop dares Duterte: Produce my 2 wives, I'll pay you P10M. (2017, January 26). ABS-CBN News. Retrieved from http://news.abs-cbn.com/news/01/26/17/ bishop-dares-duterte-produce-my-2-wives-illpay-you-p10m

Butler, J. (1997). Excitable speech: A politics of the performative. New York and London: Routledge.

CBCP Episcopal Commission on Social Communication. (2017, January 17). No Limit to the Divine Mercy - Bishop Bacani. Retrieved from http://cbcpecsc.blogspot.com/2017/01/no-limit-to-divine-mercybishop-bacani.html

CBCP Pastoral Statement on Death Penalty. (2017, March 19). CBCP News. Retrieved from https:// cbcpnews.net/cbcpnews/cbcp-pastoral-statement-on-death-penalty/

Church will not be silent amid killings --Archbishop. (2017a, January 20). CBCP News. Retrieved from http://cbcpnews.net/cbcpnews/the-church-will-not-be-silent-amid-killings-archbishop/

Cohen, S. (1972). Folk devils and moral panics: The creation of the Mods and Rocker. London \& New York: Routledge.

Death toll rises to 97; Bohol hit hard. (2013, October 15). Rappler. Retrieved from https://www.rappler. com/nation/41438-central-visayas-oct-15-quake-death-toll

De Jesus, J.L. (2017, February 6). Bato does a Duterte, hits CBCP for criticizing drug killings. Inquirer. net. Retrieved from http://newsinfo.inquirer.net/868667/bato-does-a-duterte-hits-cbcp-for-criticizingdrug-killings

Did Duterte keep or break his promise. (2017, May 29). CNN Life. Retrieved from https://cnnphilippines. com/life/culture/politics/2017/03/23/duterte-promises-and-policies-guide.html

Duterte draws huge crowd in a show of force. (2016, May 7). SunStar. Retrieved from https://www. sunstar.com.ph/article/73139 
Fact-checkers legal support initiative. (2019, September 12). Fact-checker legal guide Philippines. Retrieved from https://factcheckerlegalsupport.org/wp-content/uploads/2019/09/FCLG-Philippines.pdf

Fairclough, l., \& Fairclough, N. (2012). Political discourse analysis: A method for advanced students. London \& New York: Routledge.

Faithful urged: Support CBCP stand on issues. (2017, February 6). CBCP News. Retrieved from https:// cbcpnews.net/cbcpnews/faithful-urged-support-cbcp-stand-on-issues/

Gagliardone, I. Gal, D., Alves, T., \& Martinez, G. (2015). Countering online hate speech. Paris: UNESCO Publishing.

Habermas, J. (1989). The structural transformation of the public sphere. Cambridge: Polity Press.

Honneth, A. (2008). Reification: A new look at an old idea. Oxford \& New York: Oxford University Press.

International covenant on civil and political rights. (n.d.) Retrieved from https://www.ohchr.org/en/ professionalinterest/pages/ccpr.aspx

Jiao, C. (2017, January 5). Rodrigo Duterte: A singular man. CNN Philippines. Retrieved from https:// cnnphilippines.com/life/culture/politics/2017/01/05/rodrigo-duterte-cover-story.html

June 2017 nationwide survey on the performance and trust ratings of the top Philippine government officials and key government institutions. (2017). Pulse Asia. Retrieved from http://www.pulseasia. ph/june-2017-nationwide-survey-on-the-performance-and-trust-ratings-of-the-top-philippinegovernment-officials-and-key-government-institutions/

Kayo ang may sala: Sueno says Church failed to shepherd flock from drugs. (2017, February 23). Retrieved from https://politics.com.ph/kayo-ang-may-sala-sueno-says-church-failed-shepherd-flock-drugs/ Killings must end now, says CBCP head. (2017, February 17). CBCP News. Retrieved from http://www. cbcpnews.com/ cbcpnews/?p=91754

Kuypers, J., \& King, A. (2009). What is rhetoric? In Kuypers, J. (Ed.), Rhetorical criticism: Perspectives in action. New York \& Plymouth: Lexington Books.

Lagrimas, Nicole Annie. (2017, August 3). Don't belittle Mocha and her five million followers, Andanar tells critics. Retrieved from https://www.gmanetwork.com/news/news/nation/662867/don-tbelittle-mocha-and-her-5-million-followers-andanar-tells-critics/story/

Leader, M, J., \& Benesch, S. (2016). Dangerous speech and dangerous ideology: An integrated model for monitoring and prevention. Genocide Studies and Prevention: An International Journal, 9(3), 70-95. dx.doi.org/10.5038/1911-9933.9.3.1317

Machin, D., \& Mayr, A. (2012) How to do critical discourse analysis: A multimodal introduction. London \& Los Angeles: Sage.

Malacañang, allies outburst vs pastoral letter stuns CBCP chief. (2017, February 15). CBCP News. Retrieved from http://www.cbcpnews.com/cbcpnews/?p=91631

Maslog, C. (2017). Deconstruct to understand: Why President Duterte speaks his way. Manila: Asian Institute of Journalism and Communication.

McCombs, M., Shaw, D., \& Weaver, D. (2014). New directions in agenda-setting theory and research. Mass Communication and Society, 17(6), 781-802. DOI: 10.1080/15205436.2014.964871

Mindanao Comprised About 24 Percent of the Philippines' Total Population. (2005, June 8). Retrieved from https://psa.gov.ph/content/mindanao-comprised-about-24-percent-philippines-totalpopulation 
Mindanao priest to Duterte: Stop bullying Catholic Church. (2017, January 26). ABS-CBN News. Retrieved from http://news.abs-cbn.com/news/01/26/17/mindanao-priest-to-duterte-stop-bullyingcatholic-church

Oplan Tokhang (2017, January 21). Duterte vs CBCP - General Bato Dela Rosa resign - Trillanes the troll Donald Trump - Lenileaks [Video File]. Retrieved from https://youtu.be/i5XhG9pDcH4

Philippines: Duterte's first year a human rights calamity. (2017, June 28). Retrieved from https://www. hrw.org/news/2017/06/28/philippines-dutertes-first-year-human-rights-calamity

Presidential Communications Operations Office. (2016a, August 31). Message of President Rodrigo Roa Duterte during the Pastor's Enrichment Program (PEP) 2016 for their Annual Religious Convergence of the Jesus the Anointed One Church (JA1). Retrieved from https://pcoo.gov.ph/aug-31-2016message-of-president-rodrigo-roa-duterte-during-the-pastors-enrichment-program-pep-2016for-their-annual-religious-convergence-of-the-jesus-the-anointed-one-church-ja1/

Presidential Communications Operations Office. (2016b, December 27). Speech of rresident Rodrigo Roa Duterte during Christmas gathering with the barangay officials. Retrieved from https://pcoo.gov. ph/dec-27-2016-speech-of-president-rodrigo-roa-duterte-during-christmas-gathering-with-thebarangay-officials/.

Presidential Communications Operations Office. (2017a, January 19). Speech of President Rodrigo Roa Duterte during the Philippine National Police (PNP) oath-taking. Retrieved from https://pcoo.gov. ph/jan-19-2017-speech-of-president-rodrigo-roa-duterte-during-the-philippine-national-policepnp-oath-taking/

Presidential Communications Operations Office. (2017b, January 24). Speech of President Rodrigo Roa Duterte during his meeting with the families of the Special Action Force 44 (SAF 44). Retrieved from https://pcoo.gov.ph/january-24-2017-speech-of-president-rodrigo-roa-duterte-during-hismeeting-with-the-families-of-the-special-action-force-44-saf-44/

Presidential Communications Operations Office. (2017c, February 2). Speech of President Rodrigo Roa Duterte during the 38th national convention of Philippine association of water districts. Retrieved from https://pcoo.gov.ph/february-02-2017-speech-of-president-rodrigo-roa-duterte-during-the-38thnational-convention-of-philippine-association-of-water-districts/

Presidential Communications Operations Office. (2017d, February 3). Speech of President Rodrigo Roa Duterte during the ceremonial switch-on of the M'Lang solar powered irrigation system. Retrieved from https://pcoo.gov.ph/february-03-2017-speech-of-president-rodrigo-roa-duterte-during-theceremonial-switch-on-of-the-mlang-solar-powered-irrigation-system/

Presidential Communications Operations Office. (2017e, March 2). Speech of President Rodrigo Roa Duterte during the induction of newly-elected officers and trustees for 2017 to 2018 of the Cebu chamber of commerce and industry inc. (CCCI). Retrieved from https://pcoo.gov.ph/march-02-2017-speech-ofpresident-rodrigo-roa-duterte-during-the-induction-of-newly-elected-officers-and-trustees-for2017-to-2018-of-the-cebu-chamber-of-commerce-and-industry-inc-ccci/

Presidential Communications Operations Office. (2017f, March 2). Speech of President Rodrigo Roa Duterte during the Cebu-Cordova link expressway (CCLEX) groundbreaking ceremony. Retrieved from https:// pcoo.gov.ph/march-02-2017-speech-of-president-rodrigo-roa-duterte-during-the-cebu-cordovalink-expressway-cclex-groundbreaking-ceremony/ 
Presidential Communications Operations Office. (2017g, May 13). Speech of President Rodrigo Roa Duterte during the meeting with the Filipino community in Hong Kong special administrative region. Retrieved from https://pcoo.gov.ph/may-13-2017-speech-of-president-rodrigo-roa-duterte-during-themeeting-with-the-filipino-community-in-hong-kong-special-administrative-region/

Philippines 'War on drugs'. (2017). Retrieved from https://www.hrw.org/tag/philippines-war-drugs Ryfe, D. M. (2005). Presidents in culture: The meaning of presidential communication. NY: Peter Lang.

RTV Malacañang. (2016, October. 10). Talk to the officers and personnel of PNP-PRO 9 [Video]. YouTube. https://www.youtube.com/watch?v=McTITO2wTQ4

Sara Duterte to Villegas: You are worse than a hundred President Dutertes. (2017, February 24). ABS-CBN News. Retrieved from https://news.abs-cbn.com/news/02/24/17/sara-duterte-to-villegas-you-areworse-than-a-hundred-president-dutertes

Sasot, S.R. (2017, February 6). Kakabasa ko lang noong pastoral letter ng CBCP. [Facebook update]. Retrieved from https://www.facebook.com/forthemotherlandph/posts/ 399126373786348

Sauler, E. (2016, December 21). At Baclaran church, a Simbang Gabi shocker. Inquirer.net. Retrieved from http://newsinfo.inquirer.net/855224/at-baclaran-church-a-simbang-gabi-shocker

Second quarter 2017 Social Weather survey: Pres. Duterte's net satisfaction rating a new personal recordhigh of "very good" +66. (2017). Retrieved from https://www.sws.org.ph/swsmain/artcldisppage/? artcsyscode $=$ ART -20170706173742

Philippine Statistics Authority. (2005, June 8). Mindanao comprised about 24 Percent of the Philippines' total population. Retrieved from https://psa.gov.ph/content/mindanao-comprised-about-24percent-philippines-total-population

Stremlau, N., \& Gagliardone, I. (2019). Socio-legal approaches to online hate speech. In Creutzfeldt, N., Mason, M., and McConnachie, K. (Eds.), Routledge handbook of socio-legal theory and methods (pp. 385-397). Oxford and New York: Routledge.

Tan, K. J. (2016, November 9). CBCP in grief, says Marcos burial insult to Edsa spirit.https://news.abs-cbn. com/news/11/09/16/cbcp-in-grief-says-marcos-burial-insult-to-edsa-spirit

Tenedero, E. (2017, January 25). Bacani not backing down, urges Church execs to unite vs EJKs. ABS-CBN News. Retrieved from http://news.abs-cbn.com/news/01/25/17/ bacani-not-backing-down-urgeschurch-execs-to-unite-vs-ejks

Universal declaration of human rights. (n.d.). Retrieved from https://www.un.org/en/universaldeclaration-human-rights/

Uson, M. (2017a, December 6). Is CBCP anti-Christ? PhilStar Global. Retrieved from http://www.philstar. com/opinion/2016/12/06/1650772/cbcp-anti-christ

Uson, M. (, February 19). The Bible teaches charity... [Facebook update]. Retrieved from https://www. facebook.com/Mochablogger/posts/10155120942116522

Waldron, J. (2012). The harm in hate speech. Cambridge \& London: Harvard University Press.

What is dangerous speech. (n.d.). Dangerous speech project. Retrieved from https://dangerousspeech. org/about-dangerous-speech/ 


\section{Endnotes}

${ }^{1}$ In 2007, the Jesuit order has agreed to a tentative payout of $\$ 16$ million to settle claims that Falvey sexually abused nine Los Angeles children over 16 years ending in 1975, according to the Los Angeles Times (http://articles.latimes.com/2007/may/18/local/me-settlement18).

${ }^{2}$ The study checked the transcripts released by the PCOO against the videos.

${ }^{3}$ Uson resigned from the PCOO in October 2018 to run as a party-list candidate in the 2019 elections. She lost but has since been appointed by Duterte as deputy executive director of the Overseas Workers Welfare Administration.

${ }^{4}$ Nieto was designated consultant of the Department of Foreign Affairs in July 2017. He resigned three months later after being called to a Senate hearing on fake news.

YVONNE T. CHUA is an associate professor of the University of the Philippines Journalism Department. She was a coordinator of the collaborative fact-checking initiative Tsek.ph during the 2019 Philippines elections. She obtained her master's degree in public management from the University of the Philippines. (corresponding author:ytchua@up.edu.ph)

MA. DIOSA LABISTE is with the faculty of journalism of the University of the Philippines College of Mass Communication. She earned her doctorate from the University of Birmingham, U.K. (corresponding author: mdlabiste@up.edu.ph). 
